\title{
Public-sector patents on human DNA
}

Sir - The increasing emphasis of genomics in therapeutic and diagnostic research and development $(R \& D)$ suggests a continuing dominant role for the pharmaceutical industry in patenting human DNA. Here we present new data that challenge this broadly accepted trend by revealing that patenting activity of human DNA sequences by the US public sector is now approaching that of the private sector worldwide.

We have used patents published after filing in order to reflect more recent $R \& D$ activity. Our methodology used the GENESEQ database (Derwent Ltd, UK) to analyse patents published in 1995 that included claims for human DNA sequences. (About two-thirds were Patent Convention Treaty applications, the remainder being European Patent Office, national applications and US Patent and Trademark Office.) Strikingly, the data reveal that 40 per cent of the 652 patents originated from public-sector institutions, mainly US universities and medical charitable foundations. This figure is remarkably high and double the estimate of public-sector patenting activity in the same area between 1984 and 1995 (S. M. Thomas et al. Nature 380, 387-388; 1997).

Only half the patents were filed by the private sector. Approximately 50 per cent of the 157 companies involved were American, 21 per cent Japanese and 18 per cent from Europe (see figure). Despite the huge R\&D spend of the world's multinationals (MNEs), they have been able to claim only 26 per cent of this patent total. The small US biotechnology companies have almost equal impact, accounting for 24 per cent. By contrast, the relatively immature European small and medium-sized enterprises (SMEs) account for only 3 per cent of the total.

The US multinationals have a relatively small stake in these patents. Paradoxically, Merck, with its commitment to public release of human expressed sequence tags, is the exception, having more than any other company. Only 8 per cent of the total belong to US multinationals, a mere third of the US SME fraction. Why are these large companies not more prominent? Many, particularly those in Europe, have strategic alliances with the small US genomics companies where the emphasis may well be on the multinational partner having an

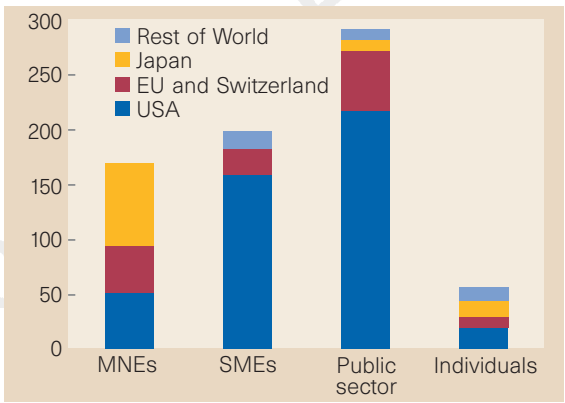

Human DNA sequence patent applications published in 1995 - nationality and sector. exclusive licence rather than ownership of a patent per se. The very recent increased patent filing activities of some multinationals will, moreover, be sufficiently represented in patent databases.

The largest single category is in the area of diagnostics. This is unsurprising as any gene sequence can be used to search for mutations in a particular gene. What is certain is that only a small proportion of these patents will actually be used. These data provide evidence of a realization on the part of public-sector scientists that patenting optimizes the chances of patients receiving benefits from their scientific research. US charities, universities and research institutes alike are filing for patents knowing that industry will not develop new treatments based on inventions without adequate intellectual property protection. We conclude that the increased rates of gene sequencing in a culture that lauds the entrepreneur are stimulating growth in patenting in both the US private and public sectors.

S. M. Thomas

N. Birtwistle

M. Brady

Science Policy Research Unit,

J. F. Burke

Department of Biochemistry,

University of Sussex,

Mantell Building,

Falmer, Brighton BN1 9RF, UK

\section{Keeping a balance}

Sir - In all the discussion I have seen of the Dearing report on higher education in the United Kingdom, an important point does not seem to have been made explicitly. For any given level of funding of research, the scientific output will be optimized for some ratio of expenditure on researchers and on their equipment. If too high a proportion is spent on equipment, expensive apparatus will be idle for some of the time; if too high a proportion is spent on scientists, many of them will have obsolete equipment. There is little doubt that this latter situation describes the position in the United Kingdom.

Moreover, if the number of claimants is excessive in relation to the available funding, a great deal of time is wasted in writing and refereeing grant applications that in spite of their good quality cannot be supported.

It is therefore imperative that the size of the claimant pool should be set firmly on a downward course, which does not seem to have been happening. Such a reduction cannot be quick or painless (or even fair) but, unless this aim can be kept firmly in mind, there must be serious concern about the future health of British science.

Hermann Bondi

Churchill College,

Cambridge CB3 ODS, UK

\section{Wisdom in physiology}

Sir - The members of the council of the International Union of Physiological Sciences and all speakers at the round table on integrative physiology at the International Congress of Physiological Sciences held in St Petersburg on 3 July unanimously support integrative or systemic physiology. They strongly believe that a new generation of physiologists needs to think at a wider level than that of molecular biology.

I agree with this "call for wisdom", as Denis Noble of the University of Oxford defined it. In my opinion, biologists are now becoming more and more like geographers, with a microscope instead of a telescope in their hands.

'Integrative physiology' means different things to different people. There are many regulatory systems in physiology, all with specific roles in different organisms. It is essential to find out more about these systems by making the field more popular.

Journals must change their policies, and help to return integrative physiology to the forefront of research. Too many articles are at present returned to authors without peer review. Some, of course, are worthy of that fate, but not all.

There are at least two reasons for hope. First, some laboratories still maintain the old tradition of systemic physiological research; and, second, 'systemic' research is far cheaper than 'molecular' research, giving more chance to small, independent laboratories and groups.

Alexander Maryanovich Military Medical Academy, 10 Commissar Smirnov Street, St Petersburg 194044, Russia 